\title{
Monthly measured primary and new productivities in the Ulleung Basin as a biological "hot spot" in the East/Japan Sea
}

\author{
J. H. Kwak ${ }^{1}$, S. H. Lee ${ }^{2}$, H. J. Park ${ }^{1}$, E. J. Choy ${ }^{3}$, H. D. Jeong ${ }^{4}$, K. R. Kim ${ }^{5}$, and C. K. Kang ${ }^{1}$ \\ ${ }^{1}$ POSTECH Ocean Science \& Technology Institute, Pohang University of Science and Technology, Pohang, 790-784, Korea \\ ${ }^{2}$ Department of Oceanography, Pusan National University, Pusan, 609-735, Korea \\ ${ }^{3}$ Korea Polar Research Institute, Korea Institute of Ocean Science and Technology (KIOST), Incheon, 406-840, Korea \\ ${ }^{4}$ East Sea Fisheries Research Institute, National Fisheries Research and Development Institute, Kwangwon, 210-861, Korea \\ ${ }^{5}$ School of Earth and Environmental Sciences/Research Institute of Oceanography, Seoul National University, Seoul, \\ 151-747, Korea
}

Correspondence to: C. K. Kang (ckkang@postech.ac.kr)

Received: 19 December 2012 - Published in Biogeosciences Discuss.: 6 February 2013

Revised: 25 May 2013 - Accepted: 27 May 2013 - Published: 1 July 2013

\begin{abstract}
The Ulleung Basin (UB), located in the southwestern part of the East/Japan Sea (EJS), is considered having an unusually high productivity for a deep basin. Recently changes have been reported in physical, chemical, and biological properties. Here we measured the primary and new productivities in the UB using a ${ }^{13} \mathrm{C}-{ }^{15} \mathrm{~N}$ dual isotope tracer technique. Measurements took place every month for the first time throughout a year for a better estimate of the annual primary production in the EJS. Temporal variations of temperature, salinity, and density $\left(\sigma_{t}\right)$ in the study area were highly seasonal as expected for an ocean in the temperate zone. Nutrient distributions reflected these seasonal fluctuations in the vertical structure of the water column. Diatoms were in general the most dominant phytoplankton ranging from 15.5 to $82.2 \%$ with an average of $42.0 \%$ (S.D. $= \pm 9.9 \%)$. Based on those average daily productivities from our monthly measurements, the annual primary, new, and regenerated production in the UB were $273.0 \mathrm{~g} \mathrm{C} \mathrm{m}^{-2} \mathrm{yr}^{-1}$, $62.6 \mathrm{~g} \mathrm{~N} \mathrm{~m}^{-2} \mathrm{yr}^{-1}$, and $48.7 \mathrm{~g} \mathrm{~N} \mathrm{~m}^{-2} \mathrm{yr}^{-1}$, respectively. Our estimated high $f$ ratio $(0.59)$ in the UB, indicated that the predominant nitrogen source for primary production was nitrate. This is comparable with the nitrogen source in a productive coastal-upwelling region. New carbon production by phytoplankton is estimated as $145.6 \mathrm{~g} \mathrm{C} \mathrm{m}^{-2} \mathrm{yr}^{-1}$ (S.D. $= \pm 40.8 \mathrm{~g} \mathrm{C} \mathrm{m}^{-2} \mathrm{yr}^{-1}$ ) which indicates that a large portion $(53.9 \%)$ of the total annual primary production might potentially be exported from the diatom-dominated euphotic zone to a deeper zone in the UB. Further intense integrated
\end{abstract}

field observations will be necessary to improve our understanding of the current marine ecosystem in the UB as an important biological production area in the EJS.

\section{Introduction}

The East/Japan Sea (hereafter the EJS) is a semi-enclosed marginal sea surrounded by the Korean peninsula, the islands of Japan, and the Russian coast. Although the area of the EJS is only about $1.01 \times 10^{6} \mathrm{~km}^{2}$, it contains several deep $(>3000 \mathrm{~m}$ ) basins and different types of subpolar fronts in the surface layer between warm and cold water masses. Because of dynamic oceanographic conditions such as large scale current systems, mesoscale eddies, subpolar front and deep water formation, the EJS has been considered as an ideal "Miniature Ocean" for studying large-scale oceanic processes (Lee et al., 2009; references therein).

The Ulleung Basin (UB) is located in the southwest of the EJS. The prevailing surface current in the UB is the Tsushima Warm Current (TWC), which branches off from the Kuroshio Current, a warm and saline ocean current of the Western Pacific Ocean (WPO). The TWC flows northward through the East China Sea (ECS) and enters the EJS through the Korea/Tsushima Strait. Upon entering the UB, the TWC flows over the top of the East/Japan Sea Proper Water (ESPW) (Chang et al., 2004). Despite the prevalence of the nutrientpoor surface water mass of the TWC, primary production 
in the southwest EJS (i.e. the UB) is relatively high compared to those in the Yamato Sea and Japan basins (Yamada et al., 2005; Hyun et al., 2009; Yoo and Park, 2009; Lee et al., 2009). Based on satellite observations from 1998 to 2006, Yoo and Park (2009) proposed that the high productivity in the region is maintained mainly by frequent wind-driven upwellings along the Korean coast throughout the seasons except winter. In contrast, Onitsuka et al. (2007) reported that the nutrient supply from the Tsushima Current through the western channel of the Tsushima/Korea Strait is the main source for the high primary production in the southwestern part of the EJS. Recent studies reported an ecologically important role of warm eddies in the UB (Kim et al., 2012; Lim et al., 2012). Kim et al. (2012) found that high chlorophyll $a$ concentrations were enhanced by eddy-induced upwelling nutrients in the UB during the summer season with a nutrient-depleted condition in the euphotic zone. In addition, Lim et al. (2012) found high early spring primary production enhanced by anticyclonic eddies, using the first Korean Geostationary Ocean Colour Imager (GOCI). A physical upward water flux movement at the periphery of the anticyclonic eddies could keep the phytoplankton in the euphotic zone to sustain high productivity in the UB, even when the stratification for a seasonal spring bloom is not well developed in the water column during early spring (Lim et al., 2012).

Recently, Chiba et al. (2008) found a dramatic change in vertical distribution of chemical properties occurring in the EJS during the last 50-60 yr, which indicate a shift in the ventilation system. In the surface layer, changes in seawater temperature, precipitation, strength of thermal fronts, volume transport by the Tsushima Current and the mixed layer depth suggest a climatic regime shift that occurred in 1976/1977 (Chiba et al., 2008). In fact, Kang et al. (2003) reported that the sea surface temperature (SST) in winter and spring steadily increased in the southern region of the EJS. Based on recent decadal surface chlorophyll $a$ concentrations from the ocean colour satellite data (SeaWiFS and MODIS), Lee et al. (2013) found that the average chlorophyll $a$ concentration from 2008-2011 was rather higher than that from 1998-2001 in the EJS, especially along the coastal areas and the sub-polar fronts. In addition, the patterns of the chlorophyll $a$ concentration such as duration and intensity of the phytoplankton spring bloom were observed to be substantially different between the two periods from 2008-2011 and 1998-2001.

At the base of all oceanic food webs critical to ecosystem functioning is phytoplankton productivity which drives the oceanic biological pump and, therefore has the potential to affect global atmospheric $\mathrm{CO}_{2}$ levels and its associated climate forcing. Changes in atmospheric $\mathrm{CO}_{2}$ can in turn have a feed back on phytoplankton productivity by changing ocean $\mathrm{pH}$, stratification, and circulation patterns. Primary production in temperate oceans shows a strong seasonality mainly caused by seasonal dynamics in physical processes including variations of light, wind, vertical mixing, and stratification, and thereby, varying nutrient concentrations in the euphotic zone (Howarth et al., 1988; Marty et al., 2008). Primary production can be operationally partitioned into new production, and regenerated production, based on the different available sources of nitrogen (Dugdale and Goering, 1967). New production is defined as the portion of primary production that utilises nitrogen supplied from outside the euphotic zone mainly by vertical mixing (Dugdale et al., 1992). In contrast, regenerated production is the portion of primary production utilising regenerated nitrogen mainly in the form of ammonium $\left(\mathrm{NH}_{4}^{+}\right)$derived from metabolic products of several biological processes within the euphotic zone. The phytoplankton productivity measured from ship-board commonly leads to an underestimation or overestimation of the overall annual production depending on the sampling season especially in midlatitudinal zones such as the EJS. In order to have a better estimate for an annual production, we measured primary and new productivities in the UB. We did this every month for more than a year, from May 2010 to June 2011. Therefore, the main objective in this study is to investigate monthly variations in the primary and new productivities according to physical and chemical properties in the UB for a better understanding of the mechanisms for such high phytoplankton productivity in the Basin as an important biological production area in the EJS.

\section{Materials and methods}

\subsection{Study sites}

To find out annual dynamics of phytoplankton community structure and primary, new, and regenerated productivities in the UB, eleven cruises were made between May 2010 and June 2011 at three stations, one located over a steep slope (UB1, $600 \mathrm{~m}$ ), the others over the deep sea (UB2 and UB3, $2160 \mathrm{~m} 2150 \mathrm{~m}$, respectively) in the UB (Fig. 1). Water sampling and onboard experiments were conducted aboard the R/V Haeyang 2000 (May 2010 and March 2011), Eardo (July and November 2010), and Tamgu 3 (the rest of the cruises).

\subsection{Water sampling}

Water samples for carbon and nitrogen uptake rates, nutrient analysis and biochemical measurements were collected from six optical depths to which $100,50,30,15,5$, and $1 \%$ of surface irradiance was determined by a secchi disk (Poole and Atkins, 1929), using a CTD-rosette system equipped with $5 \mathrm{~L}$ Niskin bottles. Additional samples to know vertical distribution of nutrients and pigments were collected at standard depths of 50, 75 (80), 100, 150, and $200 \mathrm{~m}$. Temperature and salinity were obtained with a CTD (SBE 911 Plus, Seabird Electronics Inc., Bellevue, USA). The surface mixed layer depth was defined as a density increase of 0.125 $\sigma_{t}$ from surface values (Gardner et al., 1995). Surface light 
(a)

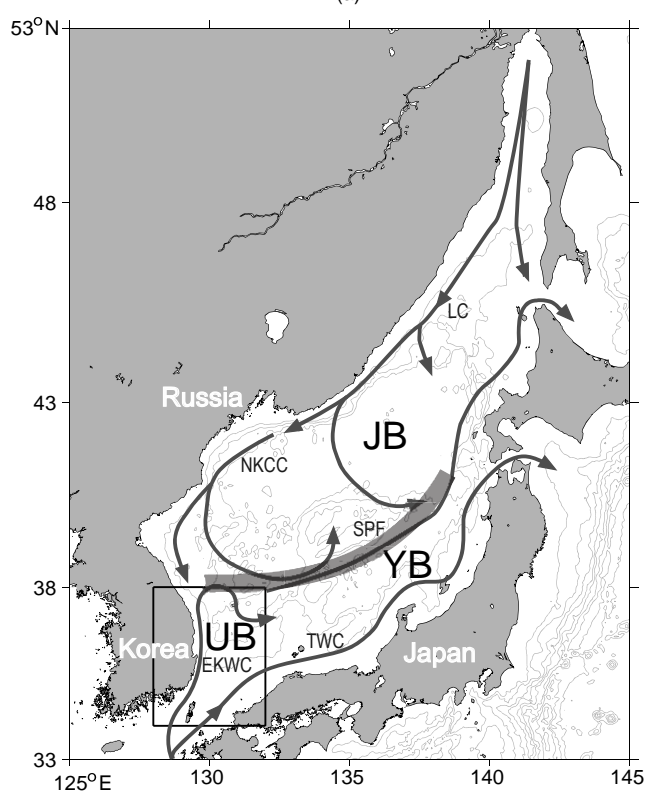

(b)

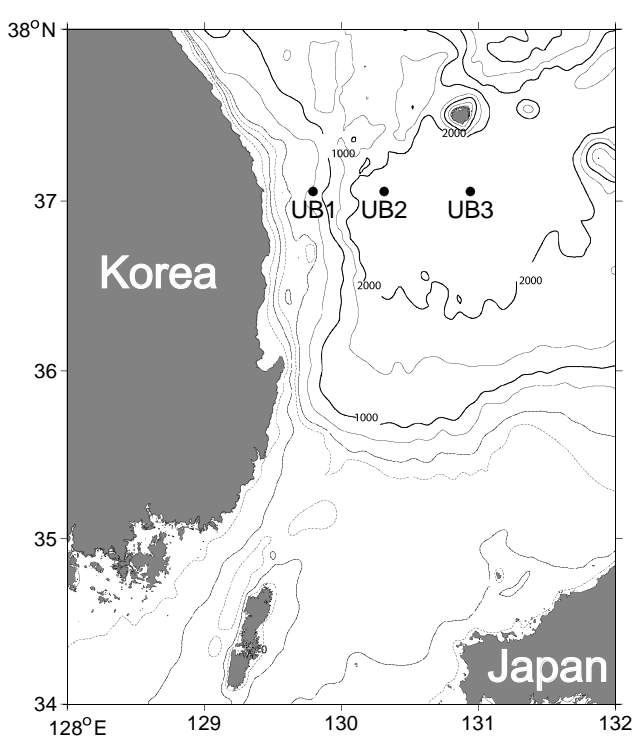

Fig. 1. Schematic map of the East/Japan Sea (a; modified from Lee et al., 2009) with sampling locations in the Ulleung Basin (b; one steep slope station, UB1 and two deep basin stations, UB2 and UB3) from May 2010 to June 2011 (LC = Liman Current, NKCC = North Korean Cold Current, EKWC = East Korean Warm Current, TWC = Tsushima Warm Current, SPF = Subpolar Front, UB = Ulleung Basin, $\mathrm{YB}=$ Yamato Basin, JB = Japan Basin).

intensity was observed on board to determine the daily and experimental irradiance using a PAR sensor (Li-1400, Li-cor Inc., Lincoln, USA). Water samples for nutrient and pigment analysis were gently filtered through $47 \mathrm{~mm}$ Whatman GF/F filters. Water samples for particulate organic carbon (POC), and nitrogen (PON) analyses were filtered through $25 \mathrm{~mm}$ pre-combusted $\left(450^{\circ} \mathrm{C}, 2 \mathrm{~h}\right)$ Whatman $\mathrm{GF} / \mathrm{F}$ filters, after prefiltration through a $200 \mu \mathrm{m}$ Nytex net. The filtered seawater samples were immediately transferred into acid-washed polyethylene bottles and frozen at $-20^{\circ} \mathrm{C}$ and the filter samples were wrapped in aluminum foil and then stored in a deep freezer $\left(-80^{\circ} \mathrm{C}\right)$ until analysis.

\subsection{Nutrient and phytoplankton pigment analysis}

In the laboratory, dissolved inorganic nitrogen $\left(\mathrm{NO}_{3}^{-}\right.$and $\left.\mathrm{NH}_{4}^{+}\right)$, phosphate $\left(\mathrm{PO}_{4}^{3-}\right)$, and silicate $\left(\mathrm{Si}(\mathrm{OH})_{4}\right)$ were determined by standard spectrophotometric methods (Parsons et al., 1984). The filters for the photosynthetic pigment analysis were extracted with $95 \%$ methanol $(5 \mathrm{~mL})$ for $12 \mathrm{~h}$ in the dark at $-20^{\circ} \mathrm{C}$ and sonicated for $5 \mathrm{~min}$ to foster cell disruption. Prior to analysis, the extracted solution was centrifuged to remove the particulate materials. Supernatant was filtered through a $0.45 \mu \mathrm{m}$ PTFE syringe filter and then $1 \mathrm{~mL}$ of filtered solution was mixed with $300 \mu \mathrm{L}$ of water. $100 \mu \mathrm{L}$ of this solution was analysed by reverse-phase highperformance liquid chromatography (Shimadzu Co. system) equipped with a Waters Symmetry $C_{8}(4.6 \times 150 \mathrm{~mm}$, particle size: $3.5 \mu \mathrm{m}, 100 \AA$ pore size) column, using the method derived from Zapata et al. (2000). Canthaxanthin was used as an internal standard to correct for analytical errors. Solvent A was methanol: acetonitrile: aqueous pyridine solution ( $0.25 \mathrm{M}$ pyridine) $(50: 25: 25, v: v: v)$ and solvent $\mathrm{B}$ was a mixture of methanol: acetonitrile: acetone $(20: 60: 20$, $v: v: v)$. Linear and step binary gradient profiles were regulated for separating pigments: $0-22 \mathrm{~min}, 40 \%$ solvent B; 22-28 min, 95\% solvent B; $28-38$ min, $95 \%$ solvent $\mathrm{B}$; 38-40 min, $100 \%$ solvent A; $40-45 \mathrm{~min}, 100 \%$ solvent A. The flow rate was fixed at $1 \mathrm{~mL} \mathrm{~min}{ }^{-1}$. The pure standard pigments, obtained from Sigma Chemical (St. Louis, MO, USA) and DHI (Hamburg, Germany), were used to determine pigment peaks and to adjust pigment concentrations on the basis of peak areas. Quantification of standard pigments was obtained by spectrophotometer with the known specific extinction coefficients after Jeffrey et al. (1997). Sample peaks were identified based on their retention time compared to those of pure standards.

\subsection{Chemotaxonomic analysis of phytoplankton pigments}

The CHEMTAX software was used to estimate phytoplankton community composition on the basis of pigment composition and concentrations (Mackey et al., 1996). The CHEMTAX programme utilises factor analysis and a suitable algorithm to determine the chlorophyll $a$ contributions of all algal groups. Twelve diagnostic biomarker pigments (i.e. chlorophyll $a$, fucoxanthin, 19'-hexanoyloxy-fucoxanthin, 
19'-butanoyloxy-fucoxanthin, neoxanthin, peridinin, chlorophyll $b$, prasinoxanthin, lutein, violaxanthin, alloxanthin, and zeaxanthin) were used for the programme. The class-specific pigment ratios, modified from the values in Lee et al. (2011) were used as the input pigment ratios of the CHEMTAX programme.

\subsection{Carbon and nitrogen uptake experiments}

Trace clean technique was used for collecting and processing samples (Fitzwater et al., 1982). Samples for carbon and nitrogen uptake experiments were pre-filtered through $200 \mu \mathrm{m}$ Nytex net and dispensed to two sets of acid-washed, transparent polycarbonate Nalgene bottles $(0.5 \mathrm{~L})$. For experiments of primary, new, and regenerated productivities, six bottles were prepared for each sampling depth. Labelled reagents were injected separately into each bottle. Duplicate experiments for measurements of carbon, nitrate, and ammonium uptake rates were performed and the values were averaged. For determination of carbon uptake rate, $\mathrm{NaH}^{13} \mathrm{CO}_{3}$ (98 atom \%, Isotec, Sigma-Aldrich, Miamisburg, OH, USA) solution was added to each sample for incubation to a final concentration of $0.2 \mathrm{mM}$, corresponding to about $10 \%$ of the ambient concentrations. $\mathrm{Na}^{15} \mathrm{NO}_{3}$ (98 atom \%, Isotec) and ${ }^{15} \mathrm{NH}_{4} \mathrm{Cl}$ (98 atom \%, Isotec) were added to each sample for determining nitrate and ammonium uptake rates, respectively. This resulted in concentrations equivalent to about $10 \%$ of the ambient nitrate and ammonium concentrations. The ambient concentration of substrate at the time of isotope additions was estimated from the long-term monitoring nutrient data provided by Annual Report of Oceanographic Observations of National Fisheries Research and Development Institute of Republic of Korea and also our own previous data obtained from the same area during several years. However, the concentrations of isotope additions were sometimes over $10 \%$ of the ambient nitrate and ammonium concentrations as some productivity stations had low ambient nutrient concentrations $(<0.1 \mu \mathrm{M})$. Although inoculating with nitrate or ammonium stable isotopes into incubation bottles might have elevated the in situ uptake rates of phytoplankton (MacIsaac and Dugdale, 1972), adding nutrient isotopes would not cause serious elevations in phytoplankton uptake rates because of the relatively short incubation time (3-5h) used in this study (Dugdale and Wilkerson, 1986). The bottles were covered with calibrated layers of neutral density screens to adjust the irradiance equivalent to those at six optical depths. Then the water samples were incubated on deck under natural light for three to four hours in order to minimise isotope dilution effects due to nitrogen recycling (Glibert et al., 1982; Kanda et al., 1987; Peña et al., 1992), starting at 08:00-09:00 and ending at local noon. Incubation temperature was regulated to be similar to in situ temperature by running surface seawater between the incubation bottles. After the incubation, the experimental water samples were gently filtered through pre-combusted $\left(450^{\circ} \mathrm{C}, 2 \mathrm{~h}\right)$ Whatman
$\mathrm{GF} / \mathrm{F}$ filters, and sample filters were stored at $-20^{\circ} \mathrm{C}$ until analysis. In the laboratory, the samples for POC, PON, and ${ }^{13} \mathrm{C}$ and ${ }^{15} \mathrm{~N}$ isotope ratio measurements were fumed with $\mathrm{HCl}$ for $2 \mathrm{~h}$ to remove carbonate and were subsequently dried at $60^{\circ} \mathrm{C}$. The dried filters were analysed with a CHN elemental analyser (Eurovector 3000 Series, Milan, Italy) coupled with a continuous-flow isotope ratio mass spectrometer (IsoPrime, GV Instruments, Manchester, UK).

Carbon uptake rate was estimated following Hama et al. (1983). Nitrogen (nitrate and ammonium) uptake rates were calculated following Dugdale and Wilkerson (1986). Daily carbon and nitrogen uptake rates were calculated by multiplying measured hourly $\mathrm{C}$ and $\mathrm{N}$ uptake rates by photoperiod conversion factors (Kanda et al., 1985; Fan and Glibert, 2005) (i.e. the ratios of daily total irradiance to integrated irradiance during incubation). Integrated uptake rates were calculated using the trapezoidal rule and integration of the entire euphotic zone (1-100\% of surface irradiance) and expressed as $\mathrm{mg} \mathrm{C} \mathrm{m}^{-2} \mathrm{~d}^{-1}$ and $\mathrm{mg} \mathrm{N} \mathrm{m}^{-2} \mathrm{~d}^{-1}$. The $f$ ratio was calculated as a fraction of nitrate uptake to the sum of nitrate and ammonium uptake (Eppley and Peterson, 1979).

\section{Results}

\subsection{Hydrography structure and inorganic major nutrient concentrations}

Vertical profiles and temporal variations of temperature, salinity and density $\left(\sigma_{t}\right)$ at the three stations during the study period represented typical seasonality of the temperate open ocean, with slightly different fluctuations among stations (Fig. 2). In general, the surface water column was more stable in spring and summer (May-September 2010) than in fall and winter (October 2010-March 2011). During the strong stratification period of Spring-Summer, a steep thermocline was observed in between the 10-20 m depth at UB1, UB2, and UB3 and thus, cold water was found within this layer. In particular, the temperature dropped below $10^{\circ} \mathrm{C}$ in between $10-20 \mathrm{~m}$ depth at Station UB1 in summer. In June 2010, cold intermediate water was expanded to $20-40 \mathrm{~m}$ depth throughout the entire study area. The highest surface temperature was observed in September $\left(27.5^{\circ} \mathrm{C}\right)$ and the lowest was recorded in March $\left(9.5^{\circ} \mathrm{C}\right)$. Salinities of surface waters were generally low $(<33.4)$ in summer (July-September 2010). The vertical profiles and temporal fluctuations of water density $\left(\sigma_{t}\right)$ with its resulting pycnocline represented a similar pattern as those of the thermocline structures. The monthly mean depth of the surface mixed layer varied largely from $5 \pm 1 \mathrm{~m}$ (September 2010) to $121 \pm 29 \mathrm{~m}$ (February 2011) during the study period (Fig. 3), showing a distinct annual cycle: shallowing during spring-summer and deepening during fall-winter.

Generally, nutrient distributions reflected seasonal fluctuations in the vertical structure of water column (Fig. 4). Only 
(a) UB1
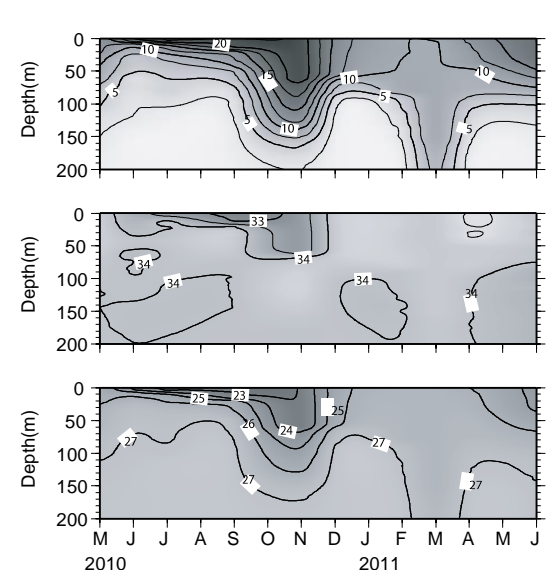

(b) UB2

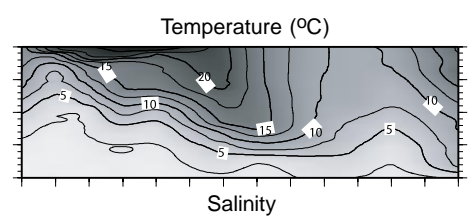

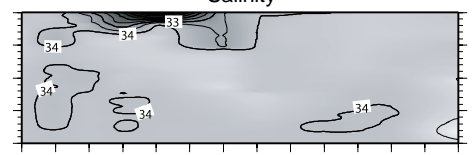

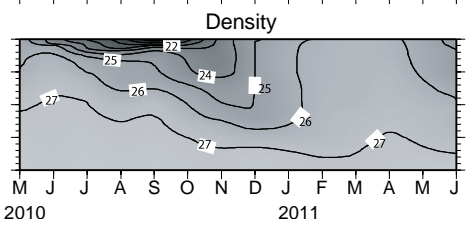

(c) UB3
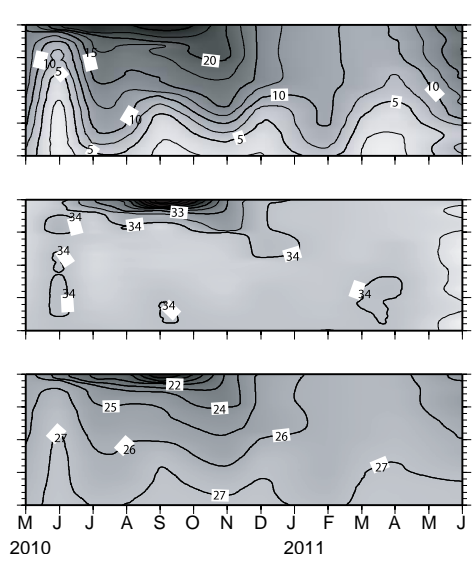

Fig. 2. Contour plots of physical parameters (temperature $\left({ }^{\circ} \mathrm{C}\right)$, salinity, and density $\left(\sigma_{t}\right)$ ) observed at the three stations during our study period.

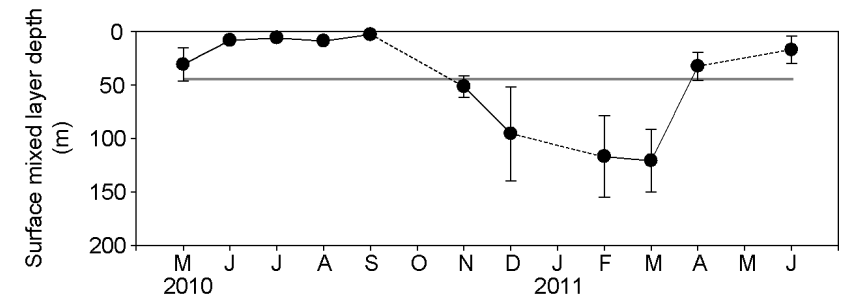

Fig. 3. Annual variation of surface mixed layer depth in the Ulleung Basin during our study period. The grey line represents an average of surface mixed layer depth.

in summer nitrate concentrations of surface waters were depleted $(<1 \mu \mathrm{M})$ at all stations when the nitracline was elevated up to the upper part of euphotic zone (20-30 m depth). In fall and winter, when stratification was weakened, surface nitrate concentration increased up to $8 \mu \mathrm{M}$ and a nitracline became unclear. Nitrate concentrations in spring and fall were lower than those in winter in the euphotic zone. Ammonium concentrations (data not shown) ranged from 0.01 to 0.91 (average \pm S.D. $=0.24 \pm 0.19$ ) between surface and $200 \mathrm{~m}$ depth. Ammonium concentrations showed no significant temporal variation with depth among sampling sites. Phosphate and silicate concentrations showed similar seasonal variations to nitrate concentrations. Silicate concentrations in spring were generally low compared to those during the other seasons. Silicate concentrations were dramatically increased particularly at the depth below the surface mixed layer in summer. Relatively low N/P ratios (4-13) compared to the Redfield ratio (16) were observed at the surface layer from spring to fall, that increased with depth. In contrast, N/P ratios (14-19) at the surface layer during late fall and winter (December 2010-March 2011) were according to the Redfield ratio, being relatively homogenous throughout the entire water column.

\subsection{Chlorophyll $a$ concentration and phytoplankton community structure}

Seasonal variations of chlorophyll $a$ concentration and group-specific chlorophyll $a$ concentrations of eight groups of phytoplankton to the total chlorophyll $a$ at each station are represented in Fig. 5. Chlorophyll $a$ concentrations from surface to $100 \mathrm{~m}$ ranged from 0 to $3.6 \mu \mathrm{g} \mathrm{L}^{-1}$, and the chlorophyll $a$ maximum layer varied with season. In early spring (April 2011), relatively higher concentrations of chlorophyll $a\left(0.2-3.4 \mu \mathrm{g} \mathrm{L}^{-1}\right)$ were observed at the surface layer. In late spring, the subsurface chlorophyll maximum (SCM) layer was well developed in the upper $75 \mathrm{~m}$ depth layer. In summer, the SCM layer was clearly observed at $10-30 \mathrm{~m}$ depth. During fall and winter, the SCM layer disappeared and chlorophyll $a$ concentrations tended to be generally low and homogeneous $\left(<0.5 \mu \mathrm{g} \mathrm{L}^{-1}\right)$ in the water column. During spring and summer 2010, the SCM layer corresponded to the depth of maximum contribution of diatoms (>90\%). In general, diatoms were the most dominant phytoplankton throughout the year except in July, 2010 (Fig. 5). The diatom contribution averaged from three stations to total phytoplankton community in the euphotic zone ranging from 15.5 to $82.2 \%$ with an average of $42.0 \%$ (S.D. $= \pm 9.9 \%$ ). Cryptophytes contributions increased in spring but decreased sharply in summer. Dinoflagellates and pelagophytes contributions increased between spring and summer at $10-40 \mathrm{~m}$ : a depth where other phytoplankton groups had very low densities. During the stratification period, cyanobacteria contributions increased at the surface layer with depleted dissolved inorganic nutrients. Contributions of prasinophytes, prymnesiophytes, and chlorophytes were very low $\left(<0.1 \mu \mathrm{g} \mathrm{L}^{-1}\right.$ at most stations).

In general, chlorophyll $a$ concentrations integrated within the euphotic zone remained relatively constant ranging from 
(a) UB
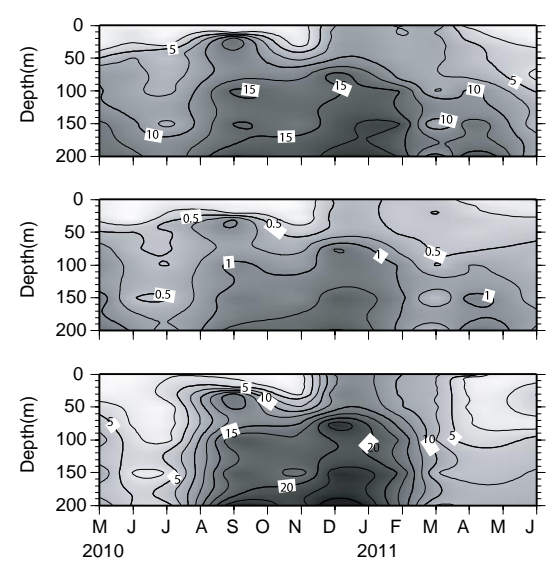

(b) UB2

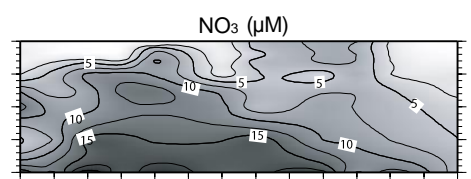

$\mathrm{PO}_{4}(\mu \mathrm{M})$

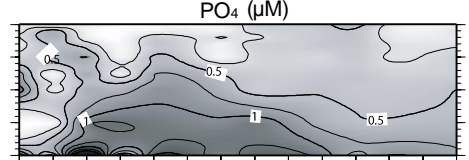

$\mathrm{SiO}_{4}(\mu \mathrm{M})$

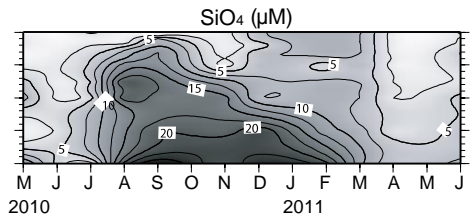

(c) UB3
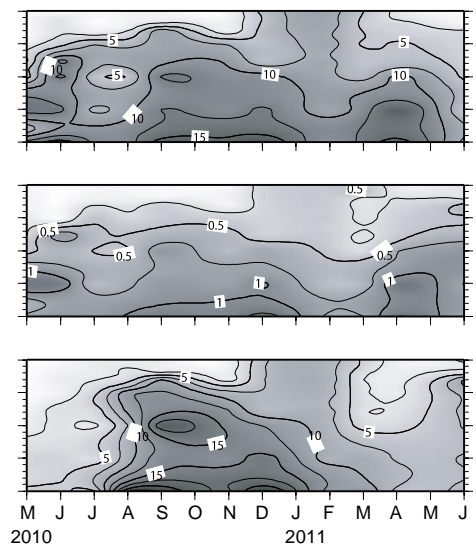

Fig. 4. Contour plots of chemical parameters (nitrate $\left(\mathrm{NO}_{3}\right)$, phosphate $\left(\mathrm{PO}_{4}\right)$, and silicate $\left(\mathrm{SiO}_{4}\right)$ ) observed at the three stations during our study period.

12.2 to $53.9 \mathrm{mg} \mathrm{m}^{-2}$ (Fig. 6). During the spring-summer stratification period, the chlorophyll $a$ concentration showed a relatively a high spatial variation (Fig. 6).

\subsection{Phytoplankton productivity and $f$ ratio}

Daily primary productivity in the euphotic zone ranged from 1.8 to $113.9 \mathrm{~m} \mathrm{C} \mathrm{m}^{-3} \mathrm{~d}^{-1}$ in terms of daily rates per cubic metre (average $\pm \mathrm{SD}=18.9 \pm 17.9 \mathrm{mg} \mathrm{C} \mathrm{m}^{-3} \mathrm{~d}^{-1}$ ) among the three productivity stations in the UB (Fig. 7). Maximum rates were mostly observed at the upper euphotic layer $(0-20 \mathrm{~m})$ throughout the year except summer. Daily new productivity ranged from 0.3 to $15.2 \mathrm{mg} \mathrm{N} \mathrm{m}^{-3} \mathrm{~d}^{-1}$ (average $\pm \mathrm{SD}=3.2 \pm 2.8 \mathrm{mg} \mathrm{N} \mathrm{m}^{-3} \mathrm{~d}^{-1}$ ) (Fig. 7). A seasonal variation of new productivity was slightly different from that of the daily primary productivity in the UB. During summer-fall, the new productivity increased with depth up to $9.9 \mathrm{mg} \mathrm{N} \mathrm{m}^{-3} \mathrm{~d}^{-1}$ at $1 \%$ light depth, but was relatively low and homogeneous in the entire water layer of the euphotic zone in winter. In comparison, daily regenerated productivity ranged from 0.2 to $26.4 \mathrm{mg} \mathrm{N} \mathrm{m}^{-3} \mathrm{~d}^{-1}$ (average $\pm \mathrm{SD}=3.7 \pm 4.8 \mathrm{mg} \mathrm{N} \mathrm{m}^{-3} \mathrm{~d}^{-1}$ ) (Fig. 7). The seasonal variation of the regenerated productivity did not usually correspond to that of the new productivity. Maximal regenerated productivities (up to $26.4 \mathrm{mg} \mathrm{N} \mathrm{m}^{-3} \mathrm{~d}^{-1}$ ) were generally observed in the upper layer of the euphotic zone $(<10 \mathrm{~m})$.

Since there was no statistical difference in phytoplankton production among the three stations in the UB, daily productivities integrated within the euphotic zone from surface to $1 \%$ optical depth were averaged for each month in Fig. 8 (one-way ANOVA, $P>0.3$ for four cases). Daily primary productivity ranged from 379.5 to $1113.7 \mathrm{mg} \mathrm{C} \mathrm{m}^{-2} \mathrm{~d}^{-1}$. The daily integrated primary productivity was maximal in spring (1074 \pm 65 and $1026 \pm 81 \mathrm{mg} \mathrm{C} \mathrm{m}^{-2} \mathrm{~d}^{-1}$ in May 2010 and June 2011, respectively) in the study re- gion (Fig. 8). The primary productivity tended to decrease gradually during summer and fall, and a minimum $\left(550 \pm 72 \mathrm{mg} \mathrm{C} \mathrm{m}^{-2} \mathrm{~d}^{-1}\right)$ was observed in November 2010. Daily integrated new and regenerated productivities ranged in between $41.2-371.3 \mathrm{mg} \mathrm{N} \mathrm{m}^{-2} \mathrm{~d}^{-1}$ and $15.5-350.7 \mathrm{mg} \mathrm{N} \mathrm{m}^{-2} \mathrm{~d}^{-1}$, respectively. Integrated regenerated productivities showed similar seasonal patterns with that of primary productivity. Regenerated productivity decreased in summer and remained relatively low during fall and winter. In contrast, integrated new productivity did not show a clear annual cycle. New productivity was highest in June, September and December 2010 coinciding with a shallowing of thermocline and nitracline. Based on the measured new and regenerated productivities in this study, generally high $f$ ratios ranging from 0.4 to 0.8 were found in the UB throughout the year. Annual variation of $f$ ratios was reversed compared to that of the surface mixed layer depth, except for September 2010 (Fig. 8).

\section{Discussion and conclusion}

Seasonal variations of primary productivity illustrate both generation and destruction of the SCM layer in the study area (Figs. 2 and 7). Surface primary productivities in spring, fall and winter (31.6-113.9, 13.4-28.9, and $6.4-22.9 \mathrm{mg} \mathrm{C} \mathrm{m}^{-3} \mathrm{~d}^{-1}$, respectively) tended to be higher than those in the subsurface euphotic zone. In summer, maximal primary productivities $\left(14.3-32.5 \mathrm{mg} \mathrm{C} \mathrm{m}^{-3} \mathrm{~d}^{-1}\right)$ were observed in the subsurface layer, coinciding with a strong stratification, and thereby surface nutrient depletion and the formation of the SCM layer. Although primary productivity in the surface layer was restricted by nutrient limitation during the stratification period, integrated primary productivity was enhanced by subsurface maximal primary productivity 
(a) UB1
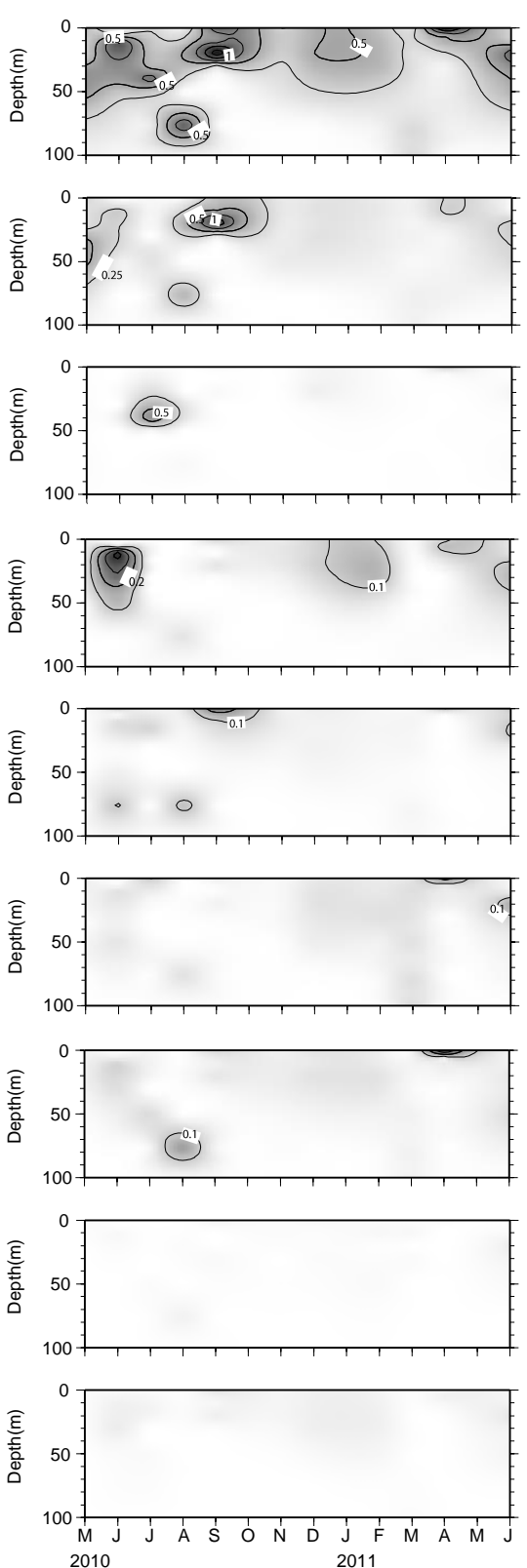

(b) UB2

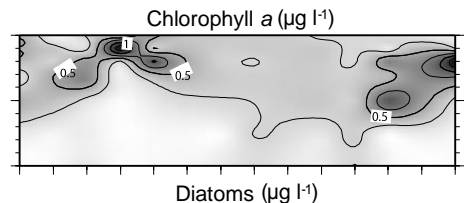

Diatoms $\left(\mu \mathrm{g} \mathrm{l}^{-1}\right)$

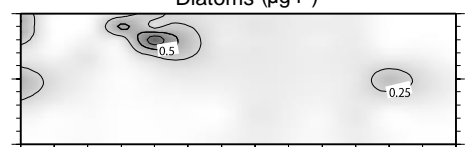

Dinoflagellates $\left(\mu \mathrm{g} \mathrm{l}^{-1}\right)$

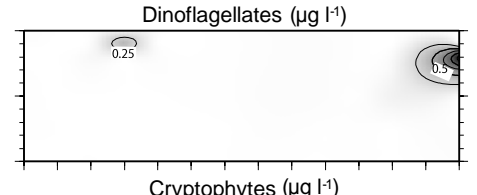

Cryptophytes $\left(\mu \mathrm{g} \mathrm{l}^{-1}\right)$

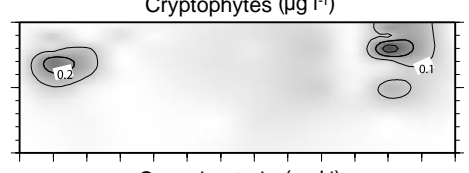

Cyanobacteria $\left(\mu \mathrm{g} \mathrm{I}^{-1}\right)$

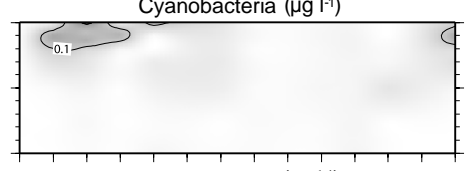

Prasinophytes $\left(\mu \mathrm{g} \mathrm{l}^{-1}\right)$

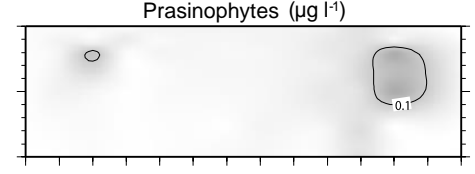

Prymnesiophytes $(\mu \mathrm{g} \mathrm{l}-1)$

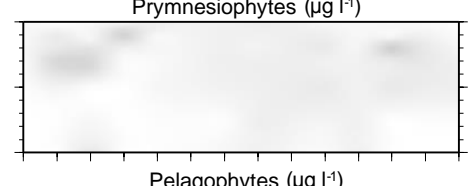

Pelagophytes $\left(\mu \mathrm{g} \mathrm{F}^{-1}\right)$

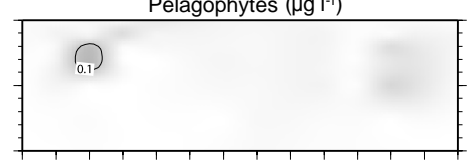

Chlorophytes $\left(\mu \mathrm{g} \mathrm{l}^{-1}\right)$

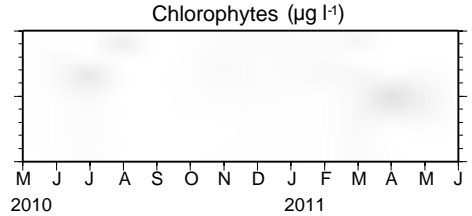

(c) UB3
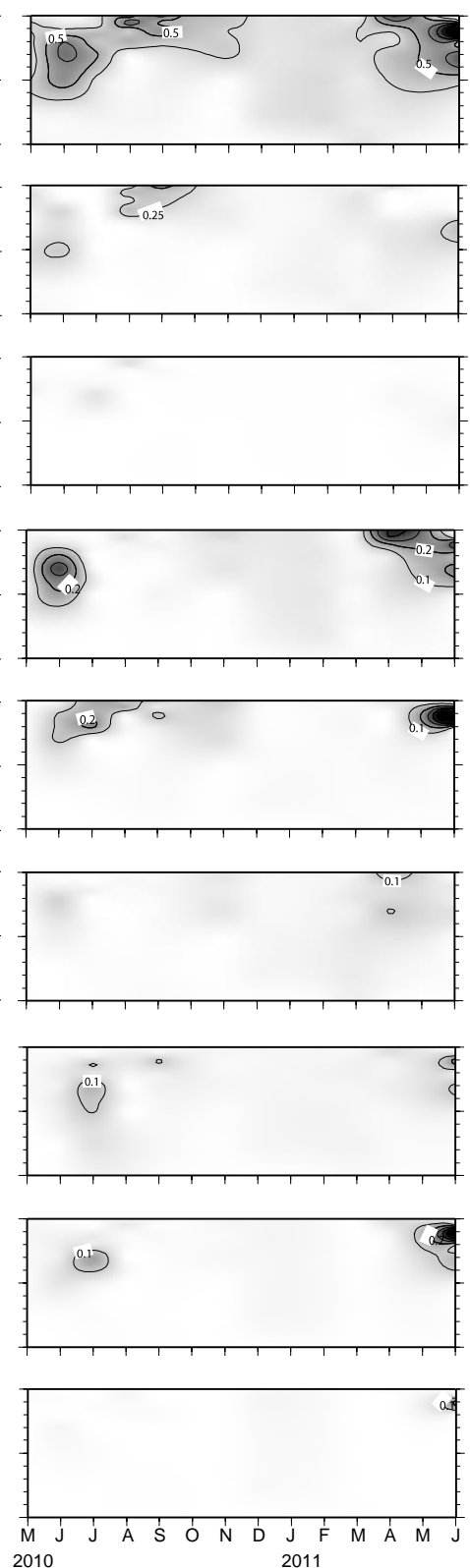

Fig. 5. Contour plots of chlorophyll $a$ and eight phytoplankton groups (diatoms, dinoflagellates, cryptophytes, cyanobacteria, prasinophytes, prymnesiophytes, pelagophytes, and chlorophytes) observed at the three stations during our study period.

and thereby remained at relatively high level compared to estimates by the satellite image.

Two uncoupled events between phytoplankton biomass and primary productivity were observed during the stratification periods. First, surface chlorophyll $a$ concentration was increased from August to September along with the enhancement of nitrate availability as reflected by the increase of new productivity and $f$ ratio (Figs. 4, 6, and 8). However, primary productivity integrated for the euphotic depth did not increase from August to September. The mismatch could be explained mainly by the existence of the SCM layer generally observed from May to October in the study region (Rho et al., 2012). Although surface chlorophyll $a$ concentration significantly increased in September, no significant difference was observed in integrated chlorophyll $a$ concentration between August and September (Student $t$ test, $P=0.619$ ) because the chlorophyll $a$ concentration at the SCM layer largely contributed to the total chlorophyll $a$ concentration (up to 

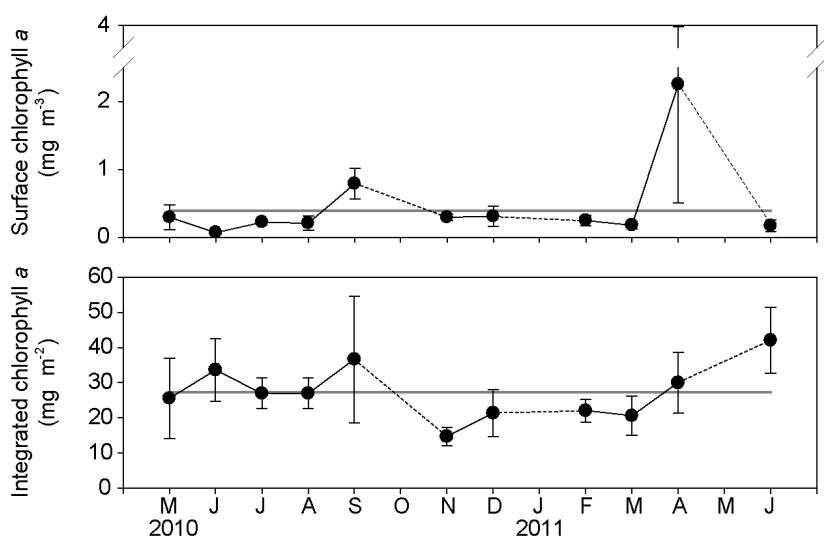

Fig. 6. Annual variations of surface and integrated chlorophyll $a$ concentration in the Ulleung Basin during our study period. The grey line represents an average of integrated chlorophyll $a$ concentration.

$87.5 \%$ ) in August. In addition, maximal primary productivity in summer was also observed at the subsurface layer near nitracline or the SCM depth without any great change from August to September (Figs. 4, 5, and 7). Second, the other interesting event was that while photosynthetic efficiency at the surface was high with low chlorophyll $a$ concentration in June, this was reversed in September (Figs. 6 and 7). Photosynthetically available radiation (PAR) peaked in May 2010 coinciding with spring bloom, and development of stratification. PAR gradually decreased from May 2010 to February 2011. During the spring bloom of the initial stage of stratification, the highest productivity was observed at the surface. In the course of stratification, the SCM layer developed and maximal productivity was observed at the subsurface. During the stratification period, phytoplankton community composition was shifted from small-sized cryptophytes in June to large-sized dinoflagellates in August and diatoms in September (Fig. 5). These phenomena may be caused by light adaptation and cell size of phytoplankton in relation to photosynthetic efficiency. Ryther (1959) distinguished phytoplankton into light adapted and non-light adapted species. While the former group can accommodate the high light intensity, the latter behaves like shade plant. Accordingly, the latter may explain dominant phytoplankton observed at subsurface layer in midsummer when water-column is stratified. If chlorophyll $a$ concentrations are uniformed, photosynthetic efficiency decreases with increasing cell size caused by self-shading effect (Morel and Bricaud, 1981; Finkel, 2001). In addition, Key et al. (2010) illustrated that small cells are more sensitive to photoinactivation of photosystem II and thereby had higher maximum metabolic rates than large diatoms.

The monthly primary productivity ranged from $379.5 \mathrm{mg} \mathrm{C} \mathrm{m}^{-2} \mathrm{~d}^{-1}$ in November to $1113.7 \mathrm{mg} \mathrm{C} \mathrm{m}^{-2} \mathrm{~d}^{-1}$ at May, 2010 with an average of $747.9 \mathrm{mg} \mathrm{C} \mathrm{m}^{-2} \mathrm{~d}^{-1}$
(S.D. $= \pm 232.8 \mathrm{mg} \mathrm{C} \mathrm{m}^{-2} \mathrm{~d}^{-1}$ ). The primary productivity (747.9 $\mathrm{mg} \mathrm{C} \mathrm{m}^{-2} \mathrm{~d}^{-1}$ ) averaged from the annual observations are almost two times higher than a previous estimate (about $400 \mathrm{mg} \mathrm{C} \mathrm{m}^{-2} \mathrm{~d}^{-1}$ ) in the UB by Yamada et al. (2005) based on satellite data to estimate PP and chlorophyll $a$ concentrations. In comparison, Kwak et al. (2013) found a rather similar summer primary productivity in the present study (Student $t$ test, $P=0.766$ ). They showed that their primary productivity was ranging from 374.5 to $964.4 \mathrm{mg} \mathrm{C} \mathrm{m}^{-2} \mathrm{~d}^{-1}$ an average of $604.5 \mathrm{mg} \mathrm{C} \mathrm{m}^{-2} \mathrm{~d}^{-1}$ (S.D. $= \pm 237.7 \mathrm{mg} \mathrm{C} \mathrm{m}^{-2} \mathrm{~d}^{-1}$ ) in the UB of the EJS which is considerably higher than those in the ECS and the WPO mainly from June-August, 2008. The main reason for the difference between this and their studies must be different seasonal measurements. They measured mainly summer primary productivity from June-August 2008 . We measured primary productivity every month from May 2010 to June 2011. Therefore, the monthly measurement for primary productivity is necessary in the UB for better estimating annual production in the region, especially at middle latitudes with significant seasonal variations in the productivity and biomass of phytoplankton.

The range of new productivity was from $41.2 \mathrm{mg} \mathrm{N} \mathrm{m}^{-2} \mathrm{~d}^{-1}$ in November to $371.3 \mathrm{mg} \mathrm{N} \mathrm{m}^{-2} \mathrm{~d}^{-1}$ in June, 2010 with an average of $171.5 \mathrm{mg} \mathrm{C} \mathrm{m}^{-2} \mathrm{~d}^{-1}$ $\left( \pm 83.5 \mathrm{mg} \mathrm{m}^{-2} \mathrm{~d}^{-1}\right)$ whereas the regenerated productivity ranged from from $15.5 \mathrm{mg} \mathrm{N} \mathrm{m}^{-2} \mathrm{~d}^{-1}$ in February to $350.7 \mathrm{mg} \mathrm{N} \mathrm{m}^{-2} \mathrm{~d}^{-1}$ in May, 2010 with an average of $133.4 \mathrm{mg} \mathrm{C} \mathrm{m}^{-2} \mathrm{~d}^{-1} \quad\left( \pm 95.6 \mathrm{mg} \mathrm{m}^{-2} \mathrm{~d}^{-1}\right)$. Kwak et al. (2013) reported that their summer time new productivity ranged from 25.9 to $221.4 \mathrm{mg} \mathrm{N} \mathrm{m}^{-2} \mathrm{~d}^{-1}$ in the UB of the EJS and the range being consistent with that in the present study (Student $t$ test, $P=0.836$ ). Given a subsurface maximum productivity and a high $f$ ratio, they confirmed that nitrate upward flux largely maintained the higher summer productivities in the UB.

Based on those average daily productivities from our monthly productivity measurements, the annual primary, new, and regenerated production in the UB were $273.0 \mathrm{~g} \mathrm{C} \mathrm{m}^{-2} \mathrm{yr}^{-1}, \quad 62.6 \mathrm{~g} \mathrm{~N} \mathrm{~m}^{-2} \mathrm{yr}^{-1}$, and $48.7 \mathrm{~g} \mathrm{~N} \mathrm{~m}^{-2} \mathrm{yr}^{-1}$, respectively. Our annual primary production (about $270 \mathrm{~g} \mathrm{C} \mathrm{m}^{-2} \mathrm{yr}^{-1}$ ) estimated in the UB from this present study was rather higher than those reported in similar regions by Lee et al. (2009), but considerably higher than those in other regions in the EJS such as along the Russian coast and in the middle of the Japan Basin (Yamada et al., 2005; Lee et al., 2009). Mean annual primary production estimates using a satellite-based primary production model were 191 and $222 \mathrm{~g} \mathrm{C} \mathrm{m}^{-2} \mathrm{yr}^{-1}$ in the southeastern and southwestern areas of the EJS, respectively, which were relatively higher than those (161-170 $\mathrm{g} \mathrm{C} \mathrm{m}^{-2} \mathrm{yr}^{-1}$ ) along the Russian coast and in the middle of the Japan Basin (Yamada et al., 2005; Lee et al., 2009). In comparison to other regions, this annual primary production in the UB as a deep basin (> $2000 \mathrm{~m}$ water depth) was remarkably higher than those 
(a) UB1
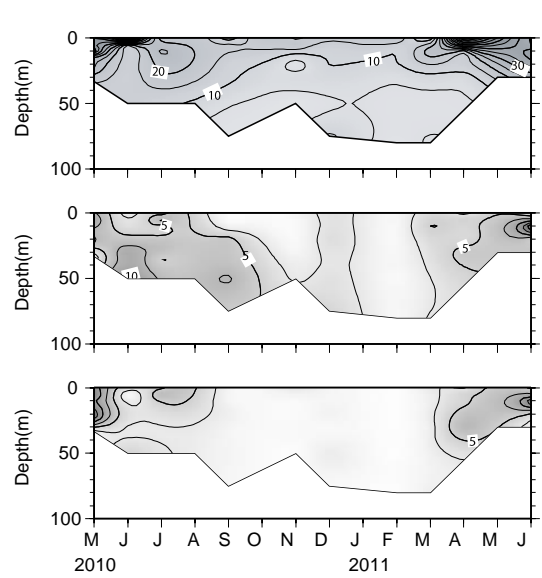

(b) UB2

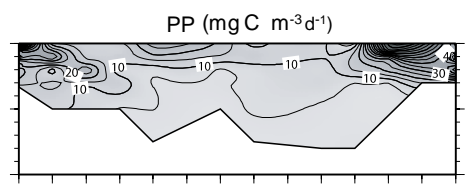

$\mathrm{NP}\left(\mathrm{mg} \mathrm{N} \mathrm{m}^{-3} \mathrm{~d}^{-1}\right)$
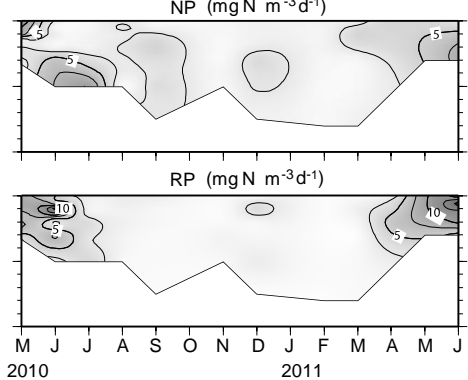

(c) UB3
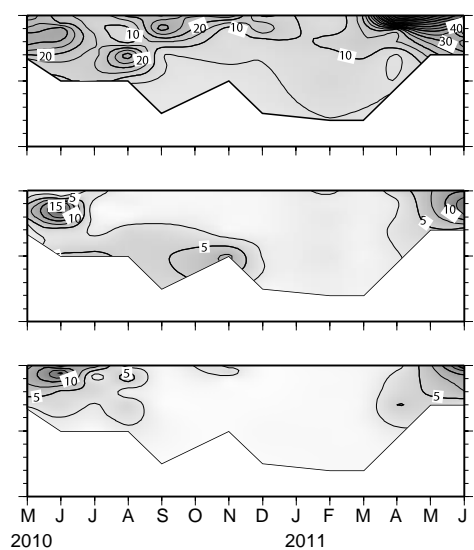

Fig. 7. Contour plots of primary productivity (PP), new productivity (NP), and regenerated productivity (RP) observed at the three stations during our study period.
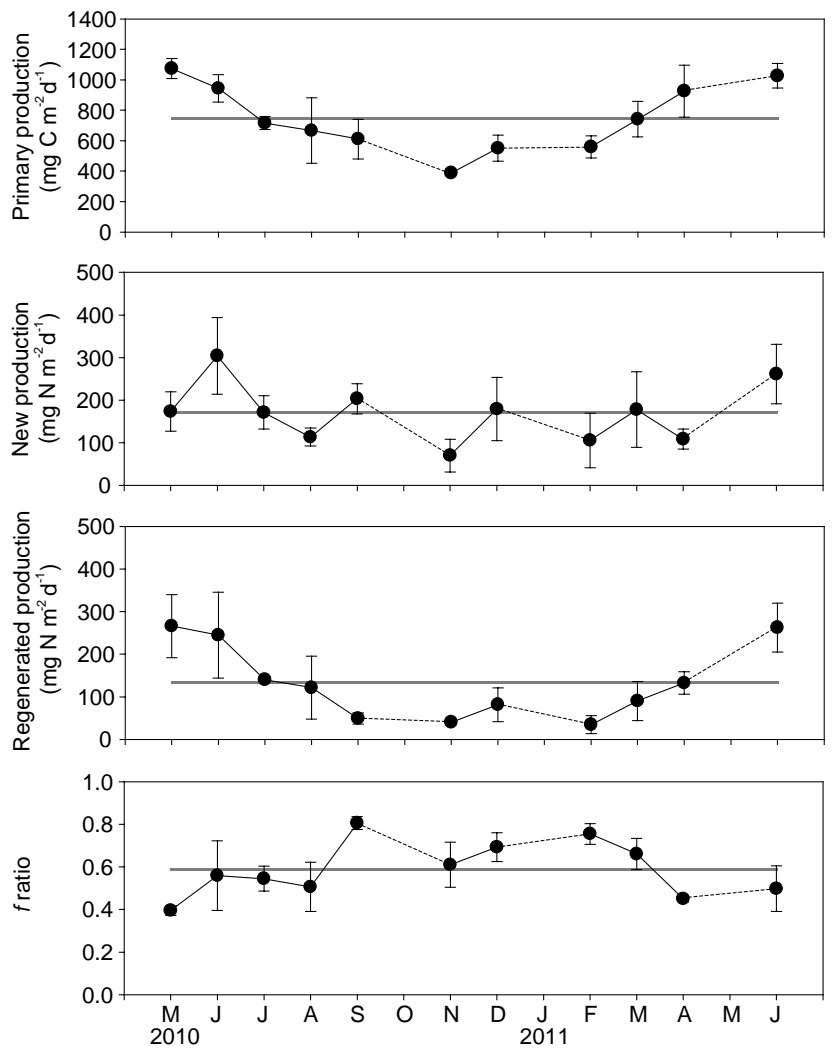

Fig. 8. Annual variations of integrated primary, new and regenerated production, and $f$ ratio in the Ulleung Basin during our study period. The grey line represents an average of each value.

in oceanic regions which are offshore waters in areas deeper than $200 \mathrm{~m}$ (Table 1). The annual primary production based on Costal Zone Colour Scanner data in the Mediterranean Sea ranged from 110 to $160 \mathrm{~g} \mathrm{C} \mathrm{m}^{-2} \mathrm{yr}^{-1}$ in the Eastern and
Western Basin, respectively (Estrada, 1996). In general, the production was less than about $100 \mathrm{~g} \mathrm{C} \mathrm{m}^{-2} \mathrm{yr}^{-1}$ in offshore ocean areas (Eppley and Peterson, 1979).

The mean assimilated $\mathrm{C} / \mathrm{N}$ ratio in the $\mathrm{UB}$ was 3.4 (S.D. $= \pm 0.8)$ in this study, which is lower than the Redfield ratio of 6.6 : 1 (Redfield et al., 1963). The possible overestimation of nitrogen uptake rates of the phytoplankton by the addition of nitrate and ammonium isotopes must be low since the ambient concentrations of nitrate and ammonium in the water column were not depleted at most of the sampling periods except in surface waters at times. Similarly, Hung et al. (2000) reported depth-integrated C/N uptake ratios of 2.06.5 within the euphotic zone in the ECS with much lower ratios in nitrate-depleted conditions and slightly lower in lightdeficient conditions. In contrast, a large variation of 0.1-25.1 in the assimilated $\mathrm{C} / \mathrm{N}$ uptake ratios has been previously reported in the Indian Ocean, those were decreasing with increasing water depth (Slawyk, 1979). Metzler et al. (1997) reported an extremely large range of $\mathrm{C} / \mathrm{N}$ uptake ratios from 0.04 to 150 at the highly stratified shelf in the South Atlantic off Brazil. They found that enhanced nitrogen uptake associated with the supply of $\mathrm{NO}_{3}^{-}$led to the lowest ratio (0.04) at $1 \%$ light depth. In comparison, the mean $\mathrm{C} / \mathrm{N}$ ratio of particulate organic matter was $5.5($ S.D. $= \pm 2.0)$ which was relatively higher than the mean assimilated $\mathrm{C} / \mathrm{N}$ uptake ratio (3.4) of phytoplankton in this study, mainly because of detritus effects on the $\mathrm{C} / \mathrm{N}$ ratio of particulate organic matter in the water column. Both lower $\mathrm{C} / \mathrm{N}$ ratios of assimilation and particulate organic matter suggest less nitrogen stress to phytoplankton growth in the UB. The phytoplankton with lower $\mathrm{C} / \mathrm{N}$ ratios provided more nitrogen-enriched food for higher trophic levels in the water column as well as for the benthic environments in the UB.

The relative importance of regenerated and new sources of nitrogen is important to distinguish because regenerated 
Table 1. Previous results of primary production, new production, and $f$ ratio in the other regions.

\begin{tabular}{|c|c|c|c|c|c|c|}
\hline Region & Note & $\begin{array}{c}\text { Primary } \\
\text { production } \\
\left(\mathrm{gC} \mathrm{m}^{-2} \mathrm{yr}^{-1}\right)\end{array}$ & $\begin{array}{c}\text { New } \\
\text { production } \\
\left(\mathrm{g} \mathrm{N} \mathrm{m}^{-2} \mathrm{yr}^{-1}\right)\end{array}$ & Reference & $f$ ratio & Reference \\
\hline Upwelling waters & & 300 & & Ryther (1969) & $0.57-0.82$ & Dugdale and Wilkerson (1992) \\
\hline Oceanic & & 50 & & Ryther (1969) & $0.03-0.21$ & Dugdale and Wilkerson (1992) \\
\hline Continental shelf & & 100 & & Ryther (1969) & & \\
\hline \multirow[t]{3}{*}{ Offshore ocean } & Indian & 84 & & Eppley and Peterson (1979) & & \\
\hline & Atlantic & 102 & & Eppley and Peterson (1979) & & \\
\hline & Pacific & 55 & & Eppley and Peterson (1979) & & \\
\hline \multirow[t]{2}{*}{ Mediterranean } & Eastern Basin & 109 & 18 & Estrada (1996) & $0.11-0.37$ & L'Helguen et al. (2002) \\
\hline & Western Basin & 158 & 52 & Estrada (1996) & 0.38 & Van Wambeke et al. (2002) \\
\hline Yellow Sea & & 141 & & Choi et al. (1988) & & \\
\hline East China Sea & & & & & $0.29-0.33$ & Kanda et al. (2003) \\
\hline South China Sea & & & & & $0.14-0.36$ & Chen (2005) \\
\hline Southern Ocean & & & & & $0.48-0.92$ & Lee et al. (2012) \\
\hline \multirow[t]{5}{*}{ East/Japan Sea } & Russian coast & 170 & & Yamada et al. (2005) & & \\
\hline & Japan Basin & 161 & & Yamada et al. (2005) & & \\
\hline & Southeastern area & 191 & & Yamada et al. (2005) & & \\
\hline & Southwestern area & 222 & & Yamada et al. (2005) & & \\
\hline & Ulleung Basin & 270 & 61 & Present study & $0.39-0.81$ & Present study \\
\hline
\end{tabular}

nitrogen maintains cells in a healthy state whereas new nitrogen increases rates of primary production and, thus the population size which is passed on to higher trophic levels (Dugdale and Goering, 1967). The ratio of new production (normally nitrate uptake) to total primary production (the sum of nitrate and ammonium uptake rates) is the $f$ ratio which is an ecologically important parameter of nitrogen uptake, providing qualitative information on the nature of the sinking POC (Eppley and Peterson, 1979). In our study, the mean annual $f$ ratio was 0.59 (S.D. $= \pm 0.14$ ), ranging from 0.4 to 0.8 (Fig. 8). This indicates that the predominant nitrogen source for primary production is nitrate and about $59 \%$ of the total annual primary production was new production in the UB. Our $f$ ratio could be overestimated, as it was estimated based solely on the relative uptake rates of nitrate and ammonium (Yool et al., 2007; Tremblay et al., 2008). For comparison, the potential nitrification was not considered here although regenerated nitrate can form more than $70 \%$ of the total nitrate pool in the euphotic zone (Yool et al., 2007). In fact, currently there are no comparable data for $f$ ratios from the EJS available since no measurements were made previously. Kanda et al. (2003) reported $f$ ratios in the ECS, that ranged from 0.29 on the shelf to 0.33 in the pelagic waters. Chen (2005) found a similar range of $f$ ratios in the South China Sea ranging from $0.29-0.36$ in early mid-March and from 0.14-0.20 from late March to October. She found the highest ratio (0.47) in winter. In the Mediterranean Sea, which has similar marine environmental conditions as those in the EJS, L'Helguen et al. (2002) reported 0.11-0.37 $f$ ratios in frontal zones and adjacent systems. Similarly, Van Wambeke et al. (2002) found that the highest mean $f$ ratio was 0.38 along the continental margin of the Gulf of Lions, northwestern Mediterranean Sea. Indeed, the $f$ ratio from this study was comparatively high compared to those, especially the ratios ( $>0.5$ ) during the summer time (Fig. 8). In fact, the mean $f$ ratio (0.59) in UB is comparable with those obtained in a eutrophic region (Dugdale and Wilkerson, 1992) and the nitrate-rich waters in the Southern Ocean (Lee et al., 2012).

Based on the $\mathrm{C} / \mathrm{N}$ uptake ratio in the each layer, new carbon production by phytoplankton was estimated as $145.6 \mathrm{~g} \mathrm{C} \mathrm{m}^{-2} \mathrm{yr}^{-1}$ (S.D. $= \pm 40.8 \mathrm{~g} \mathrm{C} \mathrm{m}^{-2} \mathrm{yr}^{-1}$ ), indicating that a large portion $(53.9 \%)$ of total annual primary production might potentially be exported from the euphotic zone to the deeper zone in the UB. This high portion of exported carbon production is correlated with the composition of phytoplankton species in the UB. Generally diatoms, as determined by levels of the pigment fucoxanthin, were dominant throughout the year with an average of $40 \%$ of their contribution to the total chlorophyll $a$ concentration in the euphotic zone in the UB (Fig. 5). Diatoms are generally considered as the most efficient phytoplankton species for a high sinking rate and thus, high biological pump efficiency, because diatoms commonly form large aggregates of settling particles (Smetacek, 2000; Ducklow et al., 2001; Honda, 2003). In fact, the average biological pump efficiency (Sarmiento and Gruber, 2006) based on nitrate concentrations in this study is about $60 \%$ in the UB which is relatively higher than those in other areas of the EJS (Lee et al., 2009). Lee et al. (2008) reported a high organic carbon content $(2.7 \%)$ in the uppermost $5 \mathrm{~cm}$ sediment in the UB reflecting a high export production. Consistently, the organic carbon flux estimation $\left(8.8 \mathrm{~g} \mathrm{C} \mathrm{m}^{-2} \mathrm{yr}^{-1}\right)$ by the time-series sediment trap at a water depth of $1,020 \mathrm{~m}$ in the UB was three times higher than that in the Bering Sea (Lee et al., 2008). Their organic carbon flux estimation $\left(8.8 \mathrm{~g} \mathrm{C} \mathrm{m}^{-2} \mathrm{yr}^{-1}\right)$ at a water depth of $1,020 \mathrm{~m}$ was about $6.0 \%$ of our estimated new production $\left(145.6 \mathrm{~g} \mathrm{C} \mathrm{m}^{-2} \mathrm{yr}^{-1}\right)$ and about $3.2 \%$ of our total production $\left(273 \mathrm{~g} \mathrm{C} \mathrm{m}^{-2} \mathrm{yr}^{-1}\right)$ in the present study. These represent 
generally high carbon fluxes for open oceans (Muller-Karger et al., 2001; Honda, 2003).

It has been argued that high productivity in the southern area (i.e. the UB) of the EJS is related to coastal upwelling (Hyun et al., 2009; Yoo and Park, 2009) and eddies (Hyun et al., 2009; Kim et al., 2012; Lim et al., 2012). Recently, Kwak et al. (2013) proposed that high phytoplankton productivity in the EJS is supported by nutrient supplies from the underlying water, which is facilitated by the hydrographic conditions. However, a combination of all these factors mentioned discussed above could sustain high productivity and high biological pump efficiency in the UB. Biological hot spots in the ocean are defined as locations where organisms tend to concentrate regularly or where there is high biological activity (Palacios et al., 2006). They are normally created by physical processes such as eddies and fronts and have distinct oceanographic signatures, which result in enhanced primary production and the aggregation of larger animals (Olson, 2002). Thus, these biological hot spots must be carefully managed from a resource management perspective and need conservation efforts (Palacios et al., 2006). In the EJS, there are different types of subpolar fronts in the surface layer between warm and cold water masses. The location of the front formation, which is usually found around $36-42^{\circ} \mathrm{N}$, $130-140^{\circ} \mathrm{E}$ around the UB, varies according to seasonal and interannual ocean conditions (Chiba et al., 2008). The role of the front in structuring the biogeography of EJS has been clearly shown in temperature, fluorescence, and primary productivity (Ashjian et al., 2006). In addition, Kang et al. (2002) previously reported that the EJS is very diverse with respect to its physical phenomena and biological characteristics. The UB can be considered as a biological "hot spot" in terms of high phytoplankton productivity and biological pump efficiency supported by hydrographic conditions that provide nutrient supplies from the underlying water (Kwak et al., 2013). This way, the UB could be an important region for the marine ecosystem in the EJS. At present, however, we do not have much knowledge about the current status and structure of the pelagic ecosystem in the Basin. More seasonal and multiannual field measurements under a variety of environmental conditions should be done to improve our understanding of the current marine ecosystem in the UB as a biological "hot spot" in the EJS. Through further intense integrated observations, we will be able to better understand how ongoing climate change affects phytoplankton productivity and higher trophic levels in the UB and the EJS.

Acknowledgements. We would like to thank Y. K. Choi for shared ship time, and the captains and crews of R/Vs Haeyang 2000, Eardo, and Tamgu 3. This research was carried out as a part of "East Asian Seas Time series-I (EAST-I)" and "Long-term change of structure and function in marine ecosystems of Korea" funded by the Ministry of Oceans and Fisheries, Korea.

Edited by: H. Liu

\section{References}

Ashjian, C. J., Arnone, R., Davis, C. S., Jones, B., Kahru, M., Lee, C. M., and Mitchell, B. G.: Biological structure and seasonality in the Japan/East Sea, Oceanography, 19, 122-133, 2006.

Chang, K.-I., Teague, W. J., Lyu, S. J., Perkins, H. T., Lee, D. K., Watts, D. R., Kim, Y. B., Mitchell, D. A., Lee, C. M., and Kim, K.: Circulation and currents in the southwestern East/Japan Sea: Overview and review, Prog. Oceanogr., 61, 105-156, 2004.

Chen Y. L.: Spatial and seasonal variations of nitrate-based new production and primary production in the South China Sea, DeepSea Res. Pt. I, 52, 319-340, 2005.

Chiba, S., Aita, M. N., Tadokoro, K., Saino, T., Sugisaki, H., and Nakata, K.: From climate regime shifts to lower-trophic level phenology: Synthesis of recent progress in retrospective studies of the western North Pacific, Prog. Oceanogr., 77, 112-126, 2008.

Choi, J. K., Park, Y. C., Kim, Y. C., Lee, Y. C., Son, S. K., Hwang, H. J., Han, B. S., and Jung, C. S.: The study on the biological productivity of the fishing ground in the western coastal area of Korea, Yellow Sea, Bull. Nat. Fish. Res. Dev. Ag., 42, 143-168, 1988.

Ducklow, H. W., Steinberg, D. K., and Buesseler, K. O.: Upper ocean carbon export and the biological pump, Oceanography, 14, 50-58, 2001.

Dugdale, R. C. and Goering, J. J.: Uptake of new and regenerated forms of nitrogen in primary productivity, Limnol. Oceanogr., 12, 196-206, 1967.

Dugdale, R. C. and Wilkerson, F. P.: The use of ${ }^{15} \mathrm{~N}$ to measure nitrogen uptake in eutrophic ocean; experimental considerations, Limnol. Oceanogr., 31, 673-689, 1986.

Dugdale, R. C. and Wilkerson, F. P.: Nutrient limitation of new production, in: Primary productivity and biogeochemical cycles in the sea, edited by: Falkowski, P. G. and Woodhead, A. D., Plenum, New York, 107-122, 1992.

Dugdale, R. C., Wilkerson, F. P., Barber, R. T., and Chavez, F. P.: Estimating new production in the equatorial Pacific Ocean at 150 W, J. Geophys. Res., 97, 681-686, 1992.

Eppley, R. W. and Peterson, B. J.: Particulate organic matter flux and planktonic new production in the deep ocean, Nature, 282, 677-680, 1979.

Estrada, M.: Primary production in the northwestern Mediterranean, Sci. Mar., 60 (Suppl. 2), 55-64, 1996.

Fan, C. and Glibert, P. M.: Effects of light on nitrogen and carbon uptake during a Prorocentrum minimum bloom, Harmful Algae, 4, 629-641, 2005.

Finkel, Z. V.: Light absorption and size scaling of light-limited metabolism in marine diatoms, Limnol, Oceanogr., 46, 86-94, 2001.

Fitzwater, S. E., Knauer, G. A., and Martin, J. H.: Metal contamination and its effect on primary production measurements, Limnol. Oceanogr., 27, 544-551, 1982.

Gardener, W. D., Chung, S. P., Richardson, M. J., and Walsh, I. D.: The oceanic mixed-layer pump, Deep-Sea Res. Pt. II, 42, 757775, 1995.

Glibert, P. M., Lipschults, F., McCarthy, J. J., and Altabet, M. A.: Isotope dilution models of uptake and remineralization of ammonium by marine plankton, Limnol. Oceanogr., 27, 639-650, 1982. 
Hama, T., Miyazaki, T., Ogawa, Y., Iwakuma, M., Takahashi, M., Otsuki, A., and Ichimura, S.: Measurement of photosynthetic production of a marine phytoplankton population using a stable isotop ${ }^{13} \mathrm{C}$ isotope, Mar. Biol., 73, 31-36, 1983.

Honda, M. C.: Biological pump in northwestern North Pacific, J. Oceanogr., 59, 671-684, 2003.

Howarth, R. W., Marino, R., and Cole, J. J.: Nitrogen fixation in freshwater, estuarine, and marine ecosystems. 1. Rates and importance, Limnol. Oceanogr., 33, 669-687, 1988.

Hung, C. C., Wong, G. T. F., Liu, K. K., Shiah, F. K., and Gong, G. C.: The effect of light and nitrate levels on the relationship between nitrate reductase activity and ${ }^{15} \mathrm{NO}_{3}^{-}$uptake: field observations in the East China Sea, Limnol. Oceanogr., 45, 836-848, 2000.

Hyun, J. H., Kim, D., Shin, C. W., Noh, J. H., Yang, E. J., Mok, J. S., Kim, S. H., Kim, H. C., and Yoo, S.: Enhanced phytoplankton and bacterioplankton production coupled to coastal upwelling and an anticyclonic eddy in the Ulleung Basin, East Sea, Aquat. Microb. Ecol., 54, 45-54, 2009.

Jeffrey, S. W.: Application of pigment methods to oceanography, in: Phytoplankton pigments in oceanography: guidelines to modern methods, edited by: Jeffery, S. W., Mantoura, R. F. C., and Wright, S. W., UNESCO Publishing, Paris, 127-166, 1997.

Kanda, J., Saino, T., and Hattori A.: Nitrogen uptake by natural populations of phytoplankton and primary production in the Pacific Ocean: Regional variability of uptake capacity, Limnol. Oceanogr., 30, 987-999, 1985.

Kanda, J., Laws, E. A., Saino, T., and Hattori, A.: An evaluation of isotope dilution effect from conventional data sets of ${ }^{15} \mathrm{~N}$ uptake experiments, J. Plankton Res., 9, 79-90, 1987.

Kanda, J., Itoh, T., Ishikawa, D., and Watanabe, Y.: Environmental control of nitrate uptake in the East China Sea, Deep-Sea Res. Pt. II, 50, 403-422, 2003.

Kang, Y. S., Kim, J. Y., Kim, H. G., and Park, J. H.: Long-term changes in zooplankton and its relationship with squid, Todarodes pacificus, catch in Japan/East Sea, Fish. Oceanogr., 11, 337346, 2002.

Kang, D.-J., Park, S., Kim, Y.-G., Kim, K., and Kim, K.-R.: A moving-boundary box model (MBBM) for oceans in change: an application to the East/Japan Sea, Geophys. Res. Lett., 30, 1299, doi:10.1029/2002GL016486, 2003.

Key, T., McCarthy, A., Campbell, D. A., Six, C., Roy, S., and Finkel, Z. V.: Cell size trade-offs govern light exploitation strategies in marine phytoplankton, Environ. Microbiol., 12, 95-104, 2010.

Kim, D., Yang, E. J., Kim, K. H., Shin, C.-W., Park, J., Yoo, S., and Hyun, J.-H.: Impact of an anticyclonic eddy on the summer nutrient and chlorophyll a distributions in the Ulleung Basin, East Sea (Japan Sea), I, ICES J. Mar. Sci., 69, 23-29, 2012.

Kwak, J. H., Hwang, J., Choy, E. J., Park, H. J., Kang, D.-J., Lee, T., Chang, K.-I. Kim, K.-R., and Kang, C.-K.: High primary productivity and f-ratio in summer in the Ulleung Basin of the East/Japan Sea, Deep-Sea Res. Pt. I, 79, 74-85, 2013.

Lee, J.-Y., Kang, D.-J., Kim, I.-N, Rho, T., Lee, T., Kang, C.-K., and Kim, K.-R.: Spatial and temporal variability in the pelagic ecosystem of the East Sea (Sea of Japan): A review, J. Marine Syst., 78, 288-300, 2009.

Lee, S. H., Kim, B. K., Yun, M. S., Joo, H., Yang, E. J., Kim, Y. N., Shin, H. C., and Lee, S.: Spatial distribution of phytoplankton productivity in the Amundsen Sea, Antarctica, Polar Biol., 35,
1721-1733, 2012.

Lee, S. H., Son, S., Dahms, H.-U., Park, J. W., Lim, J.-H., Noh, J.-H., Kwon, J.-I., and Kang, C.-K.: Decadal changes of phytoplankton chlorophyll- $a$ in the East Sea/Sea of Japan, Oceanology, in press, 2013.

Lee, T., Hyun, J.-H., Mok, J. S., and Kim, D.: Organic carbon accumulation and sulfate reduction rates in slope and basin sediments of the Ulleung Basin, East/Japan Sea, Geo-Mar. Lett., 28, 153159, 2008.

Lee, Y.-W., Park, M. O., Kim, Y.-S., Kim, S.-S., and Kang, C.-K.: Application of photosynthetic pigment analysis using a HPLC and CHEMTAX program to studies of phytoplankton community composition, J. Korean. Soc. Oceanogr., 16, 117-124. 2011.

L'Helguen S., Corre, P. L., Madec, C., and Morin, P.: New and regenerated production in the Almeria-Oran front area, eastern Alboran Sea, Deep-Sea Res. Pt. I, 49, 83-99, 2002.

Lim, J.-H., Son, S., Park, J.-W., Kwak, J. H., Kang, C.-K., Son, Y. B., Kwon, J.-N., and Lee, S. H.: Enhanced biological activity by an anticyclonic warm eddy during early spring in the East Sea (Japan Sea) detected by the geostationary ocean color satellite, Ocean Sci. J., 47, 377-385, 2012.

MacIsaac, J. J. and Dugdale, R. C.: Interaction of light and inorganic nitrogen in controlling nitrogen uptake in the sea. Deep-Sea Res., 19, 209-232, 1972.

Mackey, M. D., Mackey, D. J., Higgins, H. W., and Wright, S. W.: CHEMTAX - a program for estimating class abundances from chemical marker: application to HPLC measurements of phytoplankton, Mar. Ecol.-Prog. Ser., 144, 265-283, 1996.

Marty, J. C., Garcia, N., and Raimbault, P.: Phytoplankton dynamics and primary production under late summer conditions in the NW Mediterranean Sea, Deep-Sea Res. Pt. I, 55, 1131-1149, 2008.

Metzler, P. M., Glibert, P. M., Gaeta, S. A., and Ludlam, J. M.: New and regenerated production in the South Atlantic off Brazil, Deep-Sea Res. Pt. I, 44, 363-384, 1997.

Morel, A. and Bricaud, A.: Theoretical results concerning light absorption of phytoplankton. Deep-Sea Res., 28A, 1375-1393, 1981.

Muller-Karger, F. E., Varela, R., Thunell, R., Scranton, M., Bohrer, R., Tayler, G., Capelo, J., Astor, Y., Tappa, E., Ho, T.-Y., and Walsh, J. J.: Annual cycle of primary production in the Cariaco Basin: Response to upwelling and implications for vertical export, J. Geophys. Res., 106, 4527-4542, 2001.

Olson, D. B.: Biophysical dynamics of ocean fronts, In: Biologicalphysical interactions in the sea, edited by: Robinson, A. R. McCarthy, J. J., and Rothschild, B. J., The Sea, Vol. 12, Wiley, New York, 187-218, 2002.

Onitsuka, G., Yanagi, T., and Yoon, J. H.: A numerical study on nutrient sources in the surface layer of the Japan Sea using a coupled physical-ecosystem model, J. Geophys. Res., 112, C05042, doi:10.1029/2006JC003981, 2007.

Palacios, D. M., Bograd, S. J., Foley, D. G., and Schwing, F. B.: Oceanographic characteristics of biological hot spots in the North Pacific: A remote sensing perspective, Deep-Sea Res. Pt. II, 53, 250-269, 2006.

Peña, M. A., Harrison, W. G., and Lewis, M. R.: New production in the central equatorial Pacific, Mar. Ecol.-Prog. Ser., 80, 265-274, 1992.

Poole, H. H. and Atkins, W. R. G.: Photo-electric measurements of submarine illumination throughout the year, J. Mar. Biol. Assoc., 
16, 297-324, 1929.

Redfield, A. C., Ketchum, B. H., and Richards, F. A.: The influence of organisms on the composition of sea-water, in: The Sea, edited by: Hill, M. N., Vol.2, 26-27. Wiley, New York, 1963.

Rho, T. K., Lee, T., Kim, G., Chang, K.-I., Na, T. H., and Kim, K.R.: Prevailing subsurface chlorophyll maximum (SCM) layer in the East Sea and its relation to the physic-chemical properties of water mass, Ocean Polar Res., 34, 413-430, 2012.

Ryther, J. H.: Photosynthesis and fish production in the sea, Science, 166, 72-76, 1969.

Ryther, J. H. and Menzel, D. W.: Light adaptation by marine phytoplankton, Limnol. Oceanogr., 4, 492-497, 1959.

Sarmiento, J. L. and Gruber, N.: Ocean biogeochemical dynamics, Princeton University Press, 111 pp., 2006.

Slawyk, G.: ${ }^{13} \mathrm{C}$ and ${ }^{15} \mathrm{~N}$ uptake by phytoplankton in the Antarctic upwelling area: results from the Antiprod I Cruise in the Indian Ocean sector, Aust. J. Mar. Fresh. Res., 30, 431-448, 1979.

Smetacek, V.: The giant diatom dump, Nature, 406, 574-575, 2000.

Terry, K. L.: Nitrate uptake and assimilation in Thalassiosira weissflogii and Phaeodactylum tricornutum: interactions with photosynthesis and with uptake of other ions, Mar. Biol., 69, 21-30, 1982.

Tremblay, J.-E., Simpson, K., Martin, J., Miller, L., Gratton, Y., Barber, D., and Price, N. M.: Vertical stability and the annual dynamics of nutrients and chlorophyll fluorescence in the coastal, southeast Beaufort Sea, J. Geophys. Res., 113, C07S90, doi:10.1029/2007JC004547, 2008.
Van Wambeke, F., Heussner, S., Diaz, F., Raimbault, P., and Conan, P.: Small-scale variability in the coupling/uncoupling of bacteria, phytoplankton and organic carbon fluxes along the continental margin of the Gulf of Lions, Northwestern Mediterranean Sea, J. Marine Syst., 33-34, 411-429, 2002.

Yamada, K., Ishizaka, J., and Nagata, H.: Spatial and temporal variability of satellite primary production in the Japan Sea from 1998 to 2002, J. Oceanogr., 61, 857-869, 2005.

Yoo, S. and Park, J.: Why is the southwest the most productive region of the East Sea/Sea of Japan?, J. Marine Syst., 78, 301-315, 2009.

Yool, A., Martin, A. P., Fernández, C., and Clark, D. R.: The significance of nitrification for oceanic new production, Nature, 447, 999-1002, 2007.

Zapata, M., Rodriguez, F., and Garrido, J. L.: Separation of chlorophylls and carotenoids from marine phytoplankton: a new HPLC method using a reversed phase $\mathrm{C}_{8}$ column and pyridinecontaining mobile phases, Mar. Ecol.-Prog. Ser., 195, 29-45, 2000 . 